\title{
Notes on the vocalizations of Western Hemispingus (Hemispingus ochraceus)
}

Peter Boesman

In the following we briefly analyze and compare voice of Western Hemispingus (Hemispingus ochraceus), Black-eared Hemispingus (H. melanotis) and Piura Hemispingus (H. piurae). We also try to quantify the extent of any vocal differences using the criteria proposed by Tobias et al. (2010), as a support for taxonomic review. We have made use of sound recordings available on-line from Xeno Canto (XC).

Song of all three species is a chattering duet. A comparison, illustrated with sonograms:

\section{H. ochraceus}

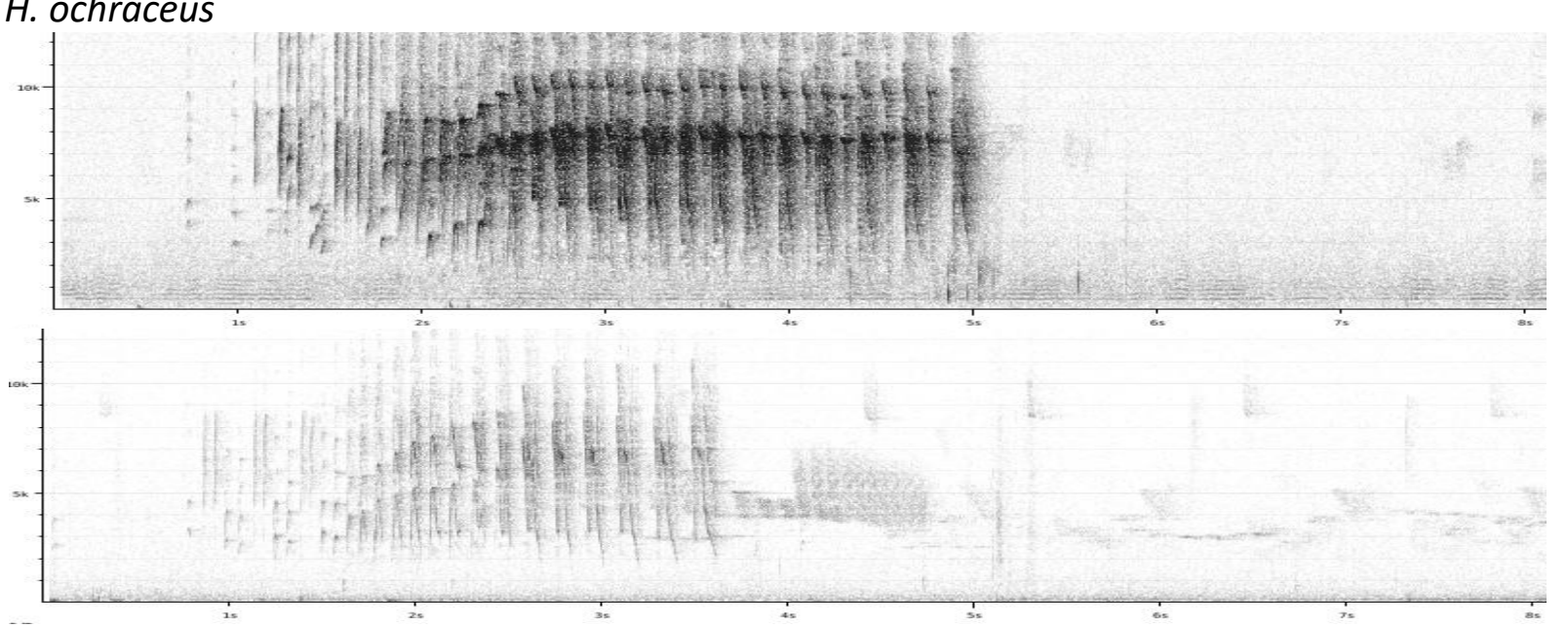

H. melanotis
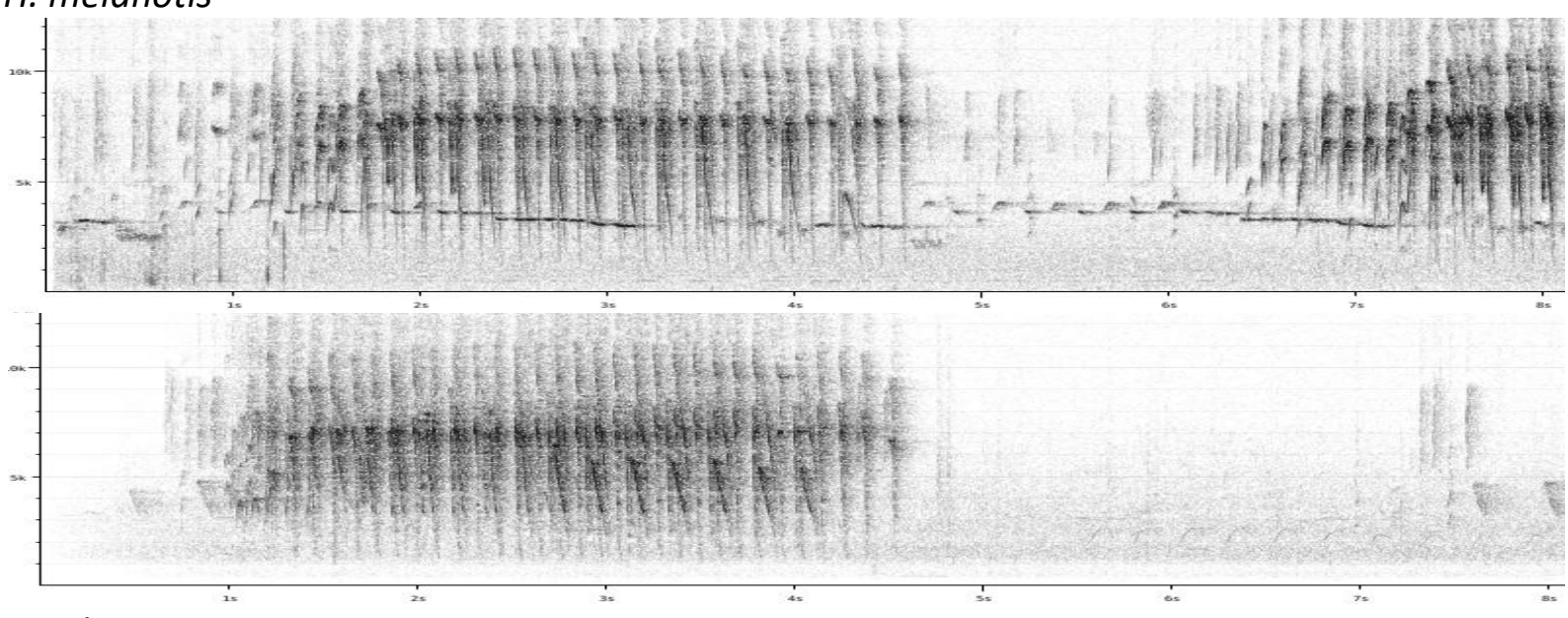

H. piurae

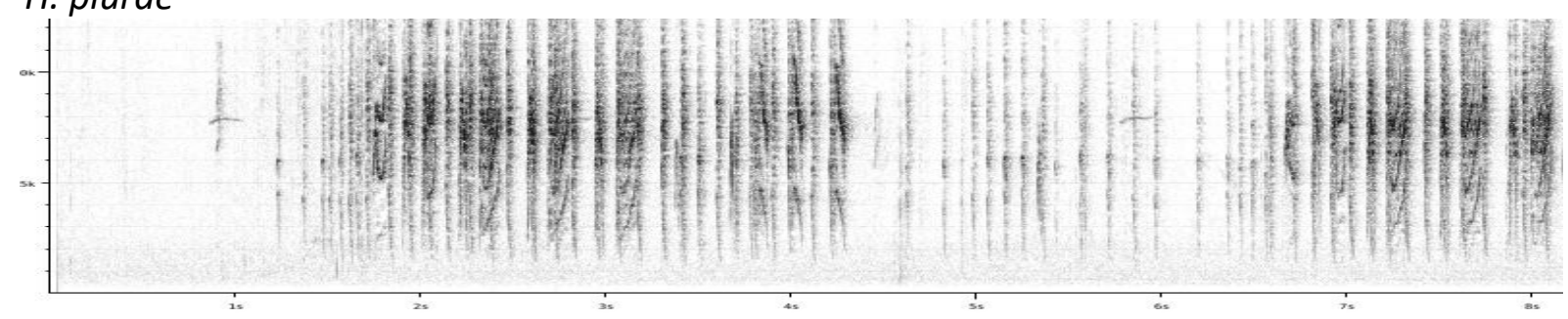




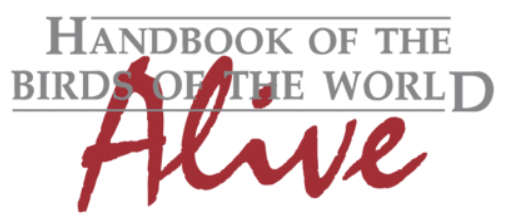

\section{ORNITHOLOGICAL NOTES}

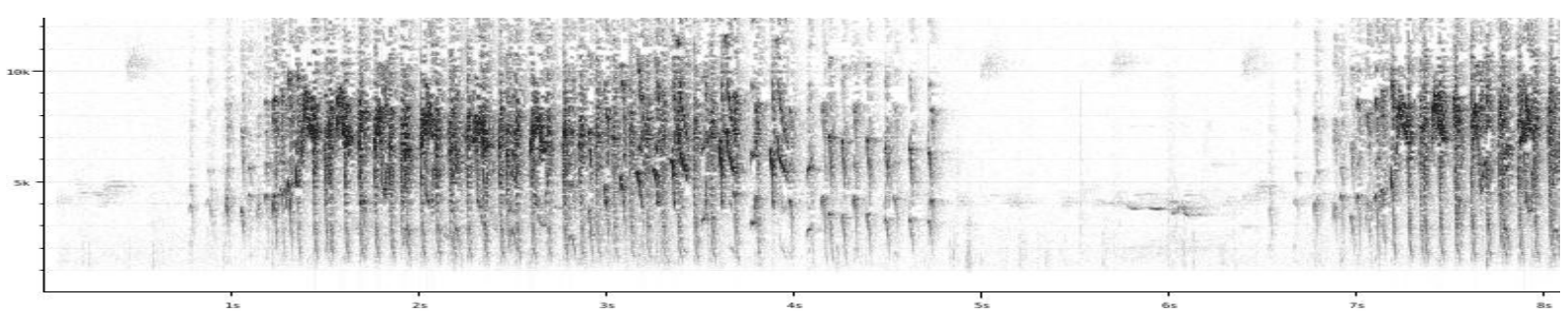

From the above, it is clear that duet song of all three species is structurally similar. There seems to be however a closer resemblance between duets of $\mathrm{H}$. ochraceus and $\mathrm{H}$. melanotis.

A closer look into details on sonogram:

\section{ochraceus}

\section{notes at start of duet}
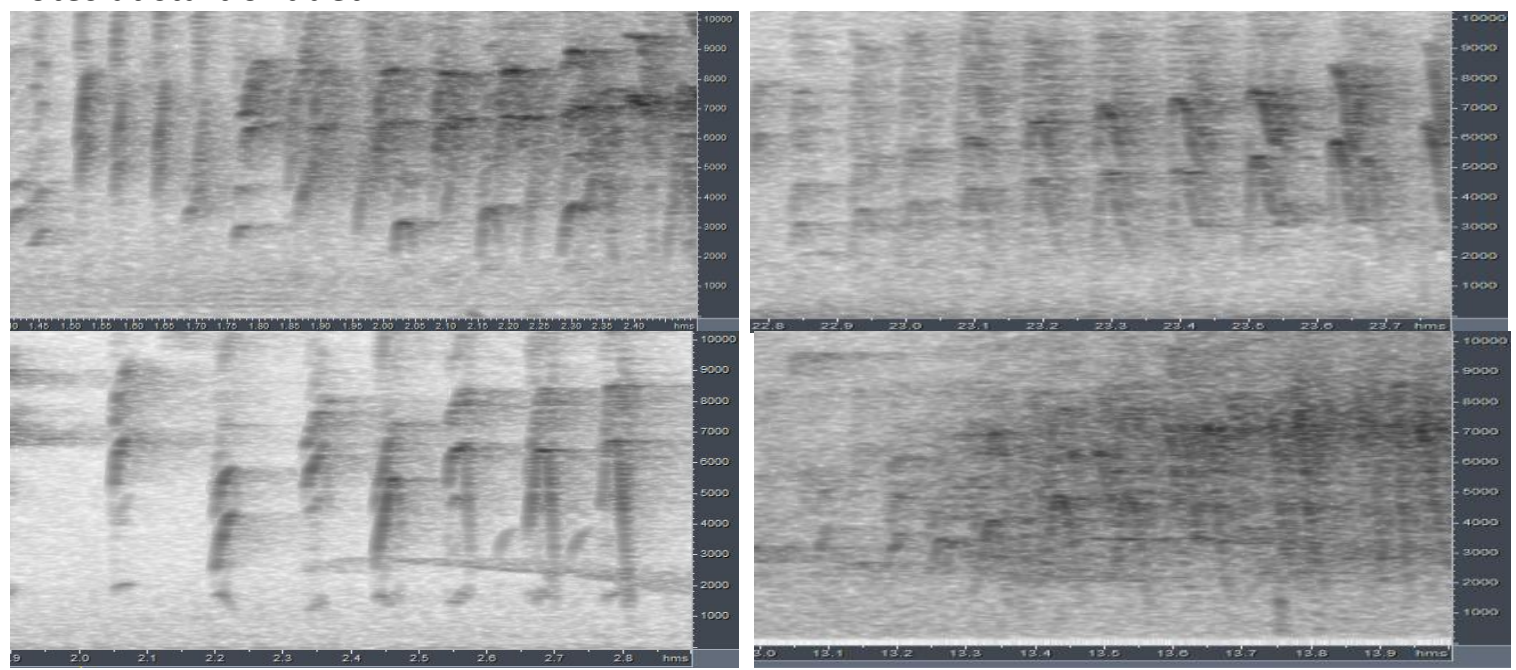

\section{notes in full duet}
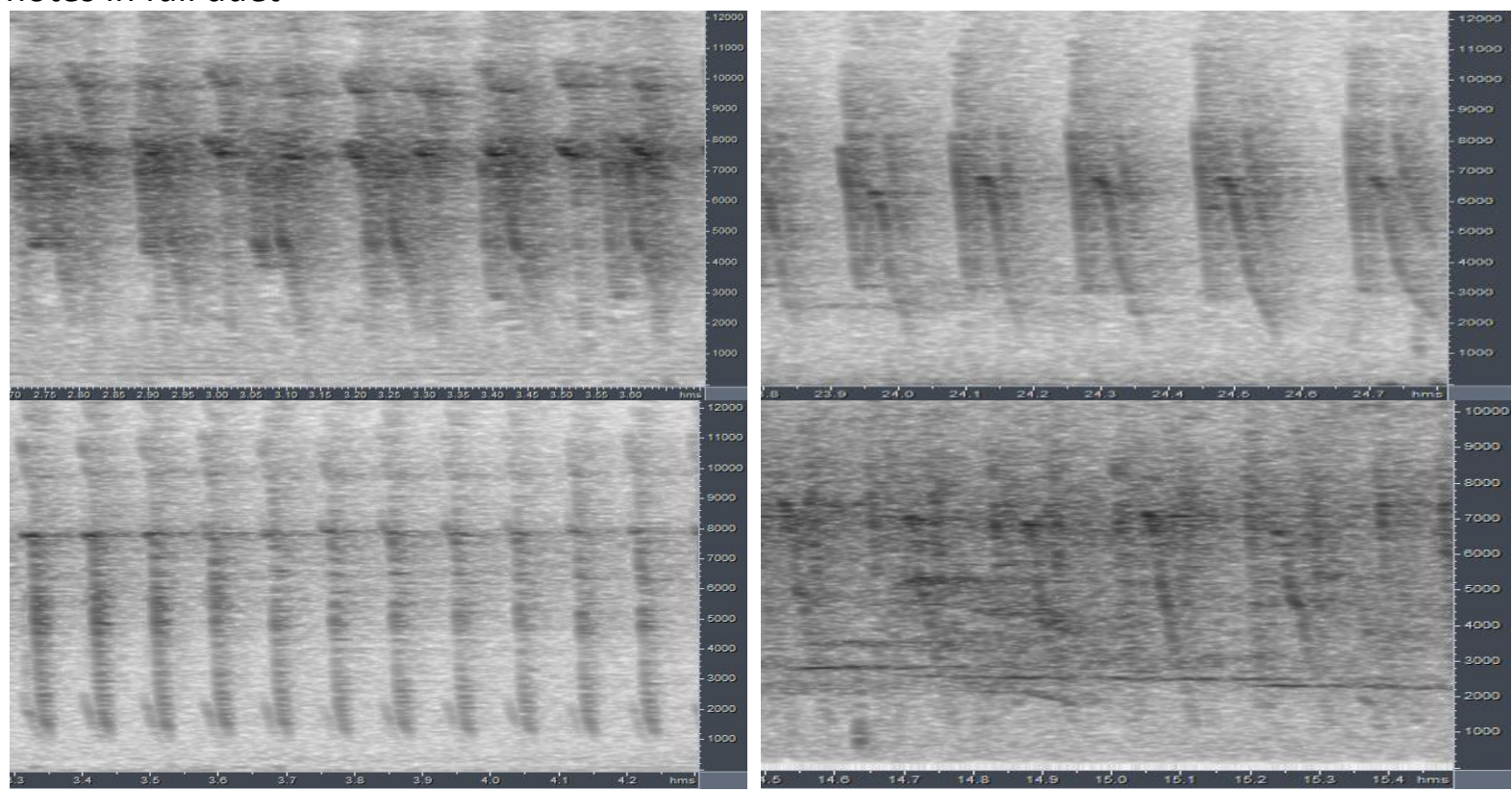


\section{HANDBOOK OF THE \\ BIRDSPFGTE WORLD}

\section{H. melanotis}

notes at start of duet

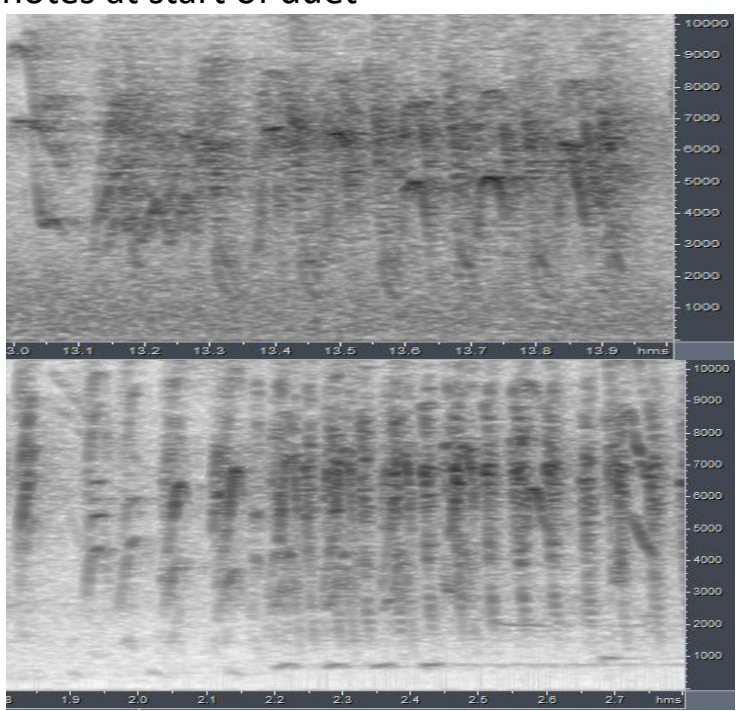

notes in full duet

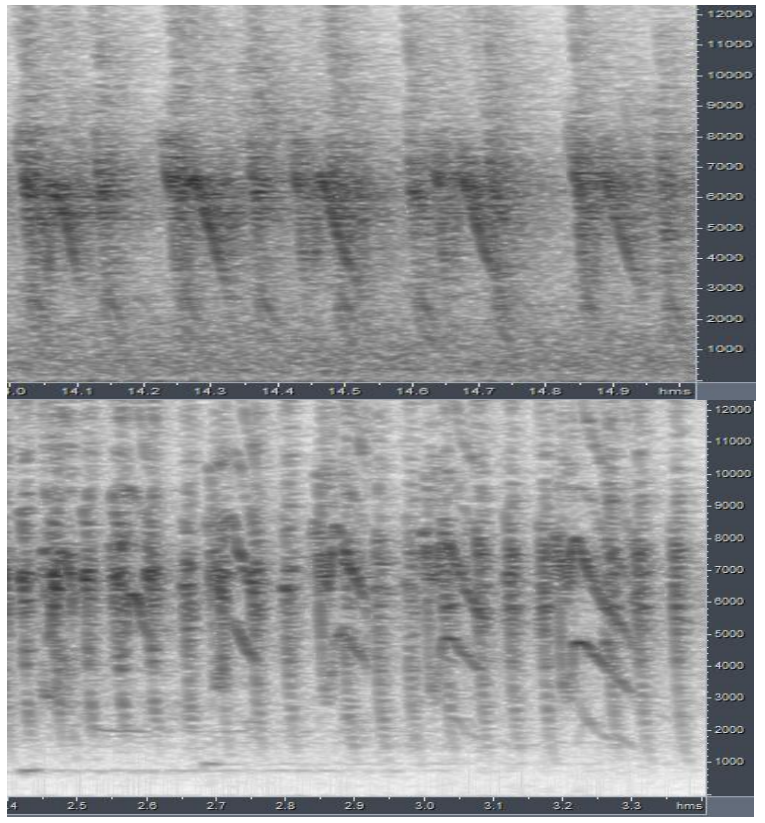

piurae

notes at start of duet

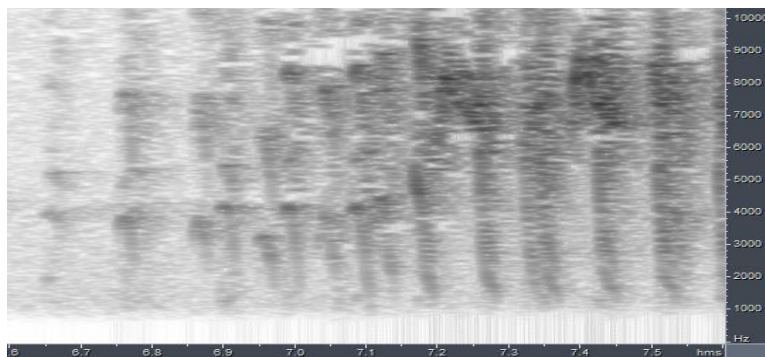

\section{ORNITHOLOGICAL NOTES}
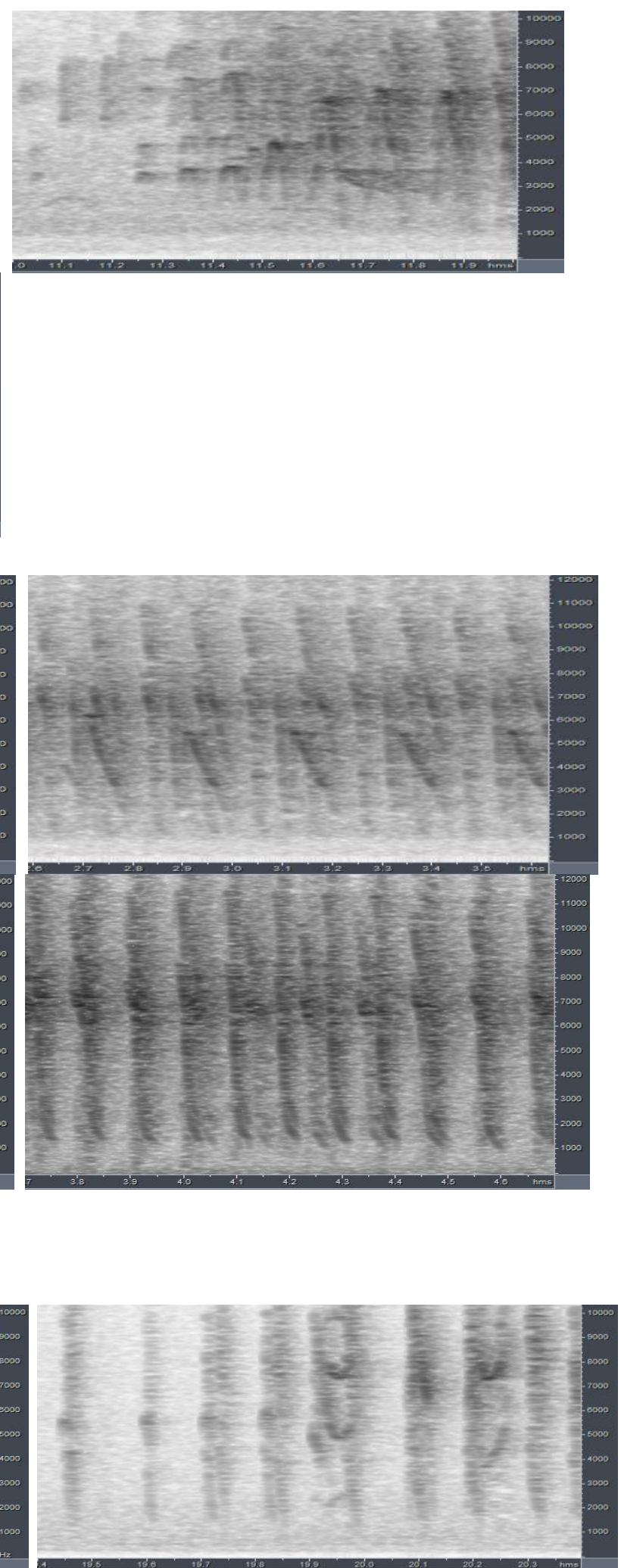

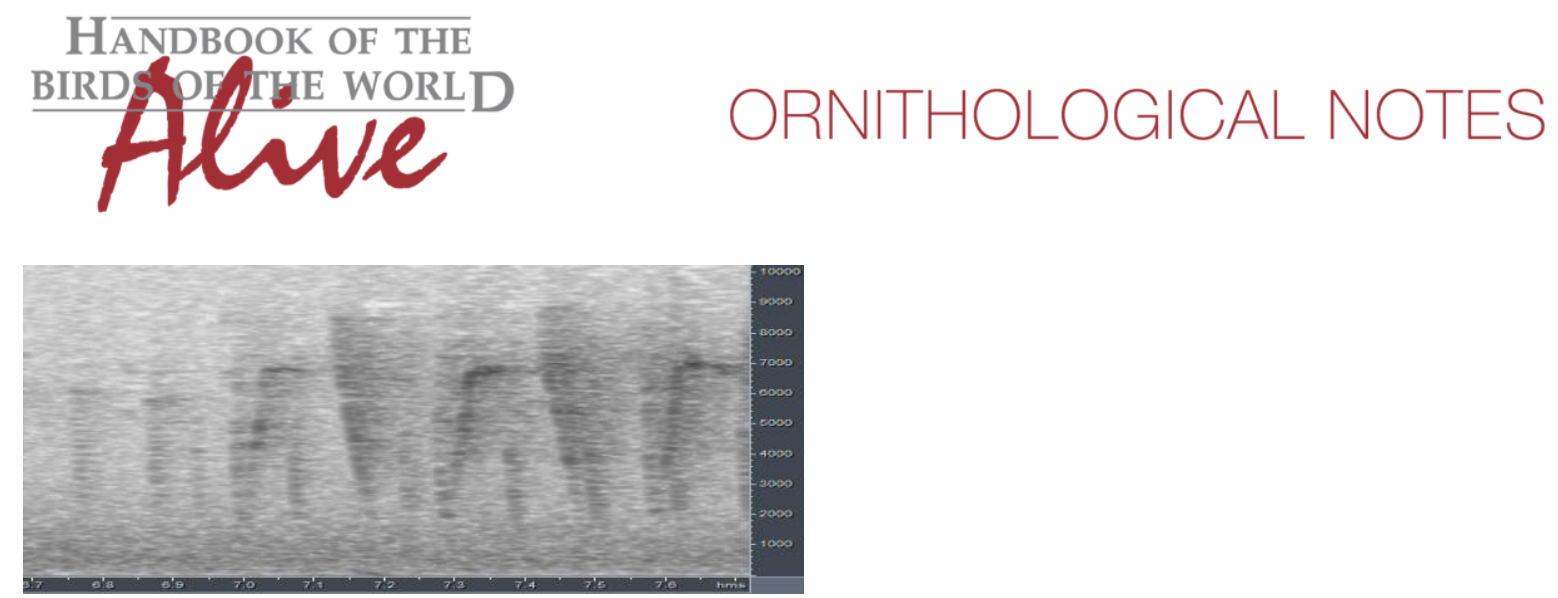

notes in full duet
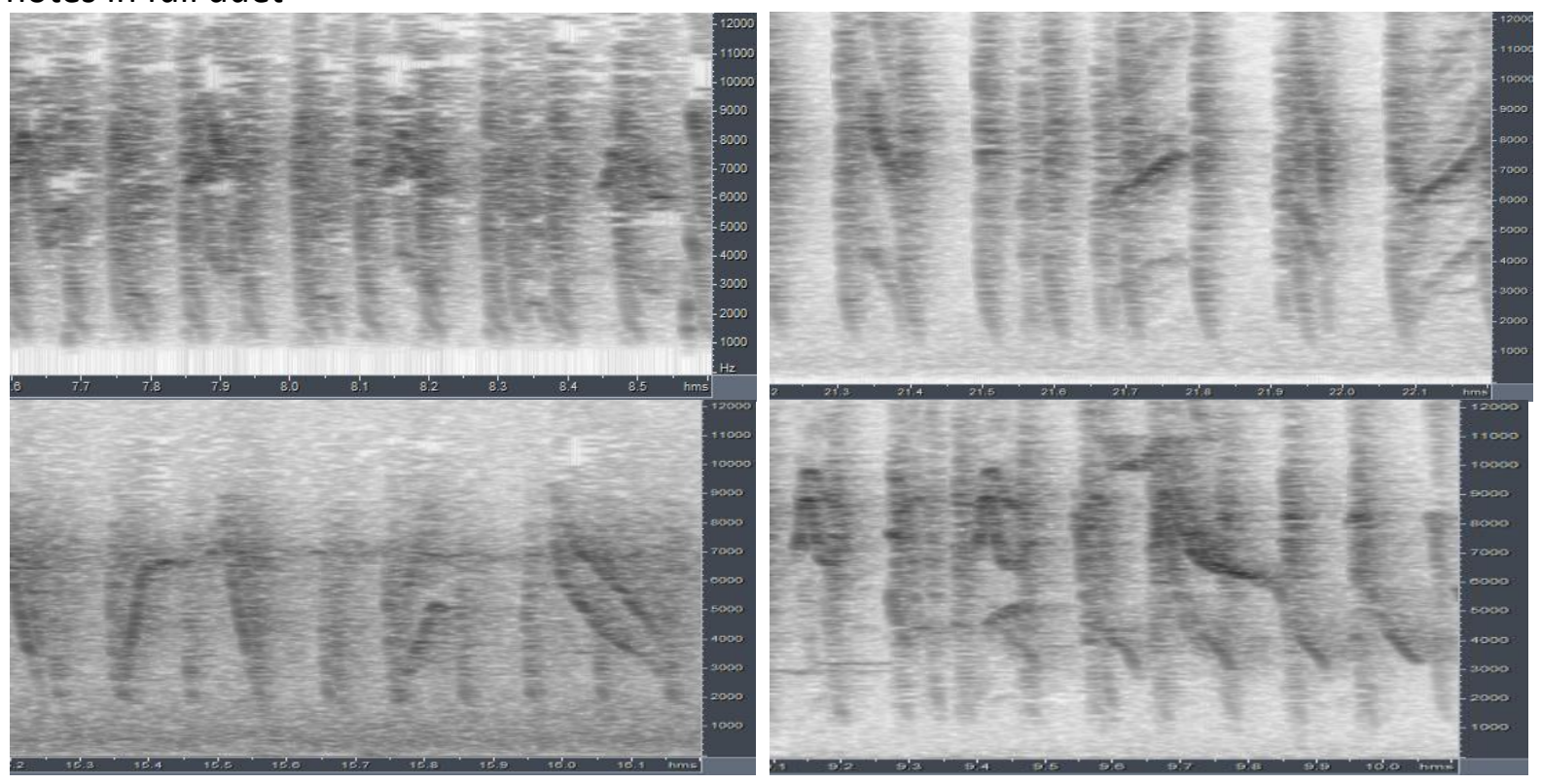

From the above examples, the similarity of ochraceus and melanotis is quite obvious: duet of ochraceus starts with some overslurred notes which gradually rise in pitch before bursting into a full duet, in which apparently both birds repeat incessantly the same note in perfect synchrony, one note very steeply downslurred, the other somewhat more gentler sloped. In melanotis, we can see exactly the same pattern, but there is slightly more variation in note shapes (which doesn't come as a surprise given the much wider range along most of the Andes).

Duet of piuirae on the other hand, is somewhat different: the start of the duet is rather a series of short notes at about the same pitch (not rising) and note shape of introductory notes slightly different (not nicely overslurred). In full duet, notes show a much less regular pattern, with apparently one of the birds switching frequently from one note to another note (either upslurred or downslurred).

Race castaneicollis of $\mathrm{H}$. melanotis also differs from other races of this species (Boesman 2016). For the sake of completeness, we therefore also depict here similar detailed sonograms of parts of its duet song: 

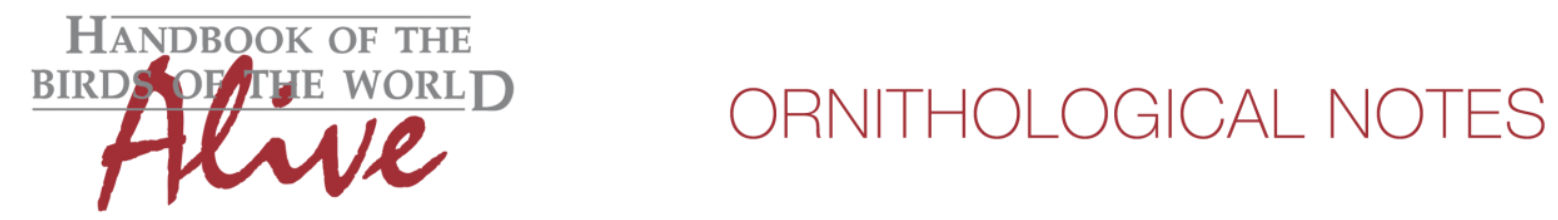

notes at start of duet
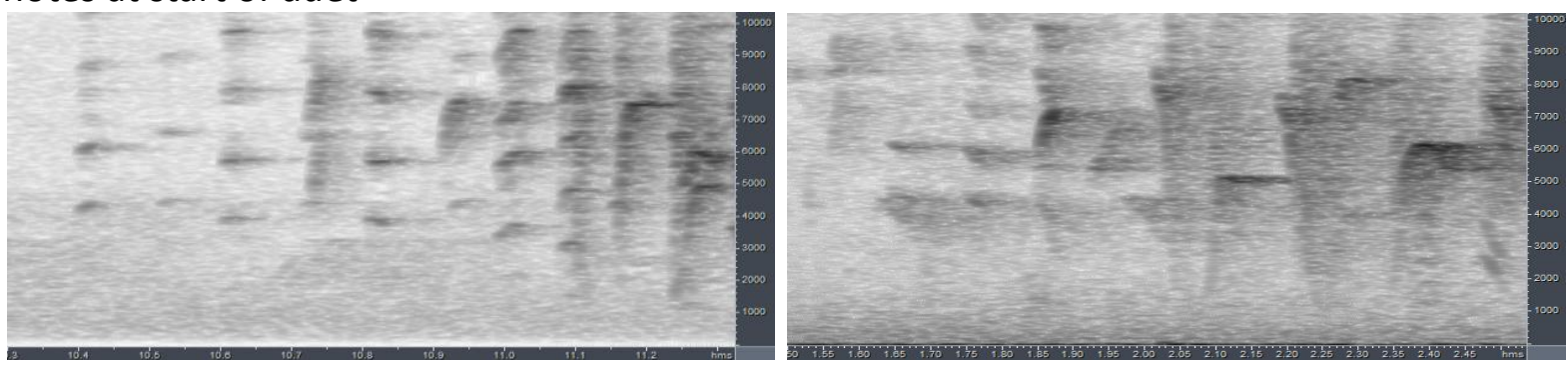

notes in full duet
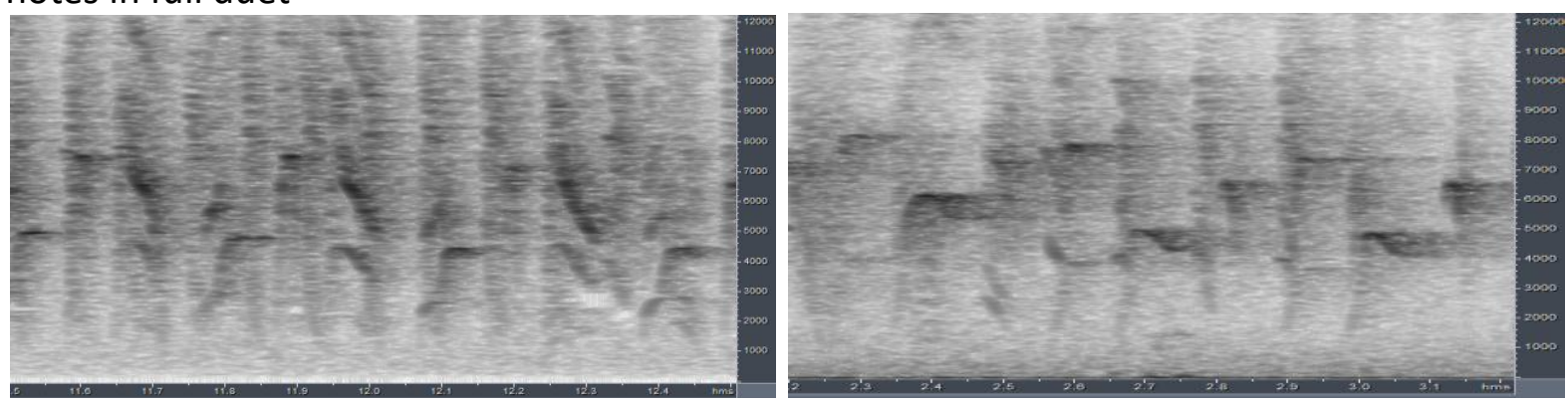

In these examples of castaneicollis note shape of introductory notes is very distinct (a vertical line of dots on a sonogram) and in full duet, there is a much less repetitive pattern, rather an alternating pattern of more curly-shaped whistles.

All in all, we can conclude that voice of $H$. ochraceus is about identical to $H$. melanotis.

Voice of piurae at the other hand is quite distinctive and can be safely told apart. Based on introductory notes at about flat pitch (1-2) and changing notes in duet (1-2) a total score of about 3 can be given. This vocal difference is about of the same magnitude as race castaneicollis within $H$. melanotis.

This note was finalized on 19th October 2016, using sound recordings available on-line at that moment. We would like to thank in particular the many sound recordists who placed their recordings for thess species on XC.

\section{References}

Boesman, P. (2016). Notes on the vocalizations of Black-eared Hemispingus (Hemispingus melanotis). HBW Alive Ornithological Note 398. In: Handbook of the Birds of the World Alive. Lynx Edicions, Barcelona. (retrieved from http://www.hbw.com/node/1253792 on 2 December 2016).

Tobias, J.A., Seddon, N., Spottiswoode, C.N., Pilgrim, J.D., Fishpool, L.D.C. \& Collar, N.J. (2010). Quantitative criteria for species delimitation. Ibis 152(4): 724-746.

\section{Recommended citation}

Boesman, P. (2016). Notes on the vocalizations of Western Hemispingus (Hemispingus ochraceus). HBW Alive Ornithological Note 443. In: Handbook of the Birds of the World Alive. Lynx Edicions, Barcelona. (retrieved from http://www.hbw.com/node/1287375 on 9 December 2016). 